\title{
SECOND RECORD OF THE RARE SPECIES PHACUS BETTKOWSKII (EUGLENOPHYCEAE)
}

\author{
DOROTA RICHTER
}

\begin{abstract}
The paper presents new data on the occurrence of Phacus bętkowskii Stawiński (Euglenophyceae). The species was found in a small midfield pond in southwestern Poland. This is its second locality in the world. The paper includes detailed morphological and metric characteristics of Ph. bętkowskii along with characteristics of its environment, particularly water physicochemistry. Research on a greater number of samples enabled emendation of the species description. Original microphotographs and line drawings of Ph. bętkowskii are presented.
\end{abstract}

Key words: distribution, ecology, euglenoids, Phacus bętkowskii, Poland

Dorota Richter, Department of Botany and Plant Ecology, Wroclaw University of Environmental and Life Sciences, Pl. Grunwaldzki 24a,50-363 Wrocław, Poland; e-mail: dorota.richter@up.wroc.pl

\section{INTRODUCTION}

The genus Phacus Dujard. comprises photosynthetic euglenoids and has a very large variety of cell shapes and pellicle surface patterns (Starmach 1983; Kočárková et al. 2005; Essen \& Leander 2010). During a study of plankton in a midfield pond in the Silesian Lowland (SW Poland) a second location of the species Phacus bętkowskii Stawiński (Euglenophyceae) was found. This is only the second locality of this species in the world.

Phacus bętkowskii was recorded for the first time in 1963 in southern Poland in Faroży pond in Landek village in the Śląsk Cieszyński region (Fig. 1) and described from limited material by Stawiński in 1969. My study of a large number of samples of $P$. bętkowskii yielded a more detailed description of its morphological and metric characteristics, and its habitat and environmental conditions (physicochemical properties) at the time of the taxon's occurrence, clarifying its morphology and completing its autecological data.

\section{MATERIAL AND LOCATION}

The midfield pond where Phacus bętkowskii was found is in SW Poland in Solniki Małe village, $12 \mathrm{~km} \mathrm{SE}$ of
Oleśnica and $2 \mathrm{~km} \mathrm{NW}$ of Bierutów, at $c a 158 \mathrm{~m}$ a.s.l. (Fig. 1). It is an artificial water body created in the 1970s for recreation and leisure. Its surface area was $5250 \mathrm{~m}^{2}$ and is now $c a 1000 \mathrm{~m}^{2}$ and still shrinking. The banks of the basin are not reinforced, the bottom is clayed, and its depth ranges between 30 and $50 \mathrm{~cm}$. The water body is surrounded by a cultivated field descending almost to the water surface. The field is used for natural crop

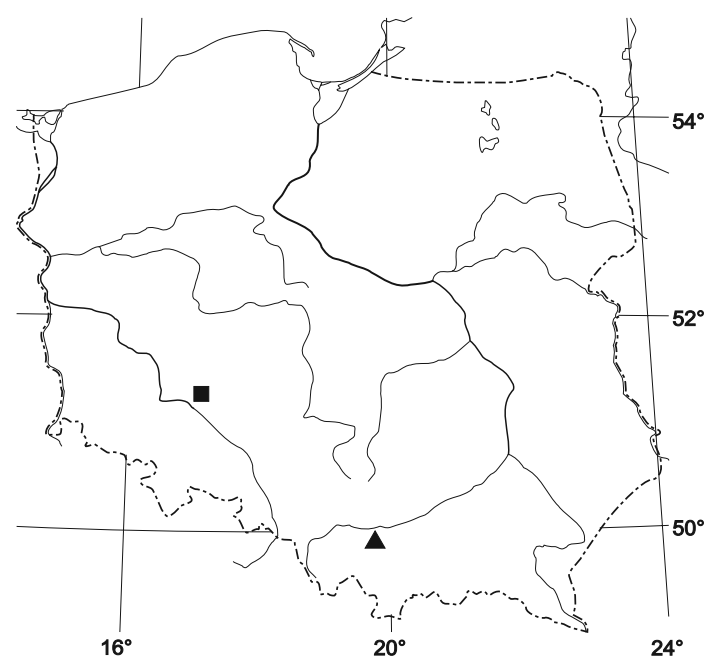

Fig. 1. Distribution of Phacus bętkowskii Stawiński, previously known locality (triangle), new locality (square). 
rotation with Triticum vulgare Host. and Brassica napus subsp. oleifera (DC.) Metzg.

The studied water body is almost entirely overgrown with rush vegetation. In the northern, western and southern parts of the basin a highly developed strip of reed mace rush (Typhetum latifoliae Soó) grows on a large area of the basin surface and bottom, reaching as far as the basin's center. Typha latifolia L. penetrates aggregations of Schoenoplectus lacustris (L.) Palla. The water surface is covered with Lemna trisulca $\mathrm{L}$., which creates a monospecific cluster of Lemno-Spirodeletum Koch 1954 occupying a third of the water surface. Also on the water surface are Ranunculus aquatilis L. and R. trichophyllus Chaix, and at the bottom Ceratophyllum submersum L. with admixture of Chara globularis Thuill creates an underwater meadow at the bottom of the reservoir.

The studied water ecosystem is characterized by a rich and interesting phycoflora. Among the plankton the most species-rich group is the Chlorophyceae (accounting for more than $29 \%$ of all identified species), Bacillariophyceae (almost 17\%), Euglenophyceae (over 16\%), Cyanobacteria (over 16\%) and Xantophyceae (over 14\%). Other groups (Chrysophyceae, Charopyceae) were recorded in small numbers. Considerable diversity was noted in the coccoid plankton species from Chlorophyta [Chlorella vulgaris Beij., Ankistrodesmus fusiformis Corda, Coelastrum astroideum De Not., C. microporum Näg., Crucigenia tetrapedia (Kirchn.) W. West \& G. S. West, Pandorina morum (Müll.) Bory, Pediastrum boryanum (Turp.) Menegh., P. tetras (Ehrenb.) Ralfs, Tetraedron caudatum (Corda) Hansg., T. minimum (A. Br.) Hansg., Scenedesmus spp.] and several filamentous species [e.g., Binuklearia tektorum (Kütz.) Beger and Microspora floccosa (Vaucher) Thuret.]. Most of the cyanobacteria were heterocytous species [Anabaena cylindrica Lemmerm., A. felisii (Men.) Bornet \& Flah., A. flos-aquae Bréb. ex Bornet \& Flah., A. oscillarioides Bory, Calothrix clavata G. S. West and Nodularia spumigena Mertens]. Some nonheterocytous filamentous species were also noted, such as Oscillatoria limnosa C. Agardh, O. tenuis C. Agardh ex Gomont and the coccoid species Merismopedia glauca (Ehrenb.) Kütz., Microcystis flos-aquae (Witt.) Kirchner and Woronichinia naegeliana (Unger) Elenkin. Among the Euglenophyceae, Phacus Dujard. and Euglena Ehrenb. were most diverse [Phacus acuminatus Stokes, Ph. corculum Pochm., Ph. orbicularis Hübner, Ph. pleuronectes (Ehrenb.) Dujard., Ph. skujai Skvortsov, Euglena limnophila Lemmerm., E. proxima Dangeard, E. texta (Dujard.) Hübner]. Lepocinclis acus (O. F. Müll.)
Marin \& Melkonian, L. oxyuris (Schmarda) Marin $\&$ Melkonian also occurred. Among the Euglenophyceae, Phacus acuminatus Stokes and Ph. bętkowskii were more numerous. Among the Xantophyceae, most numerous were Ophiocytium bicuspidatum Lemmerm., O. parvulum A. Braun and Tribonema viride Pascher. In 2006-2008 the communities of phycoflora did not show any significant differences in the quantity of the taxa between years, except for species of the Xantophyceae and Euglenophyceae families, which increased during the growing seasons (July-August) of 2007 and 2008. More numerous among the Euglenophyceae were Ph. acuminatus and Ph. bętkowskii, and among the Xantophyceae, Ophiocytium bicuspidatum Lemmerm., O. parvulum A. Braun and Tribonema viride Pascher. The increased number of Tribonema and Ophiocytium parvulum and the occurrence of Typha latifolia are characteristic for eutrophic waters (Starmach 1968; Round 1984; Kłosowski 1992). Their mass development indicates high eutrophication, supported by high values of nitrate nitrogen, total nitrogen and $\mathrm{PO}_{4}{ }^{3-}$ (Table 1), most likely due to the proximity of farmland.

The research was carried out in 2006-2008. Samples were collected every month from April to October for three vegetation seasons. The material was collected with a plankton net made of flour mesh ( $25 \mu \mathrm{m}$ mesh). The material was collected $0.5 \mathrm{~m}$ from the shore. The

Table 1. Physicochemical properties of water samples from the studied midfield pond. ${ }^{*}$ - according to Stawiński (1969).

\begin{tabular}{|c|c|c|}
\hline Data & April 2006 & August 2007 \\
\hline$\overline{\mathrm{pH}}$ & $\left(6.5^{*}\right) 7.1$ & 7.6 \\
\hline Color (mg Pt l-1) & 125.0 & 132.0 \\
\hline Conductivity $\left(\mu \mathrm{S} \mathrm{cm}{ }^{-1}\right)$ & 712.0 & 732.0 \\
\hline Oxidation $\left(\mathrm{COD}_{\mathrm{Mn}}\right)\left(\mathrm{mg} \mathrm{l}^{-1}\right)$ & 16.4 & 16.5 \\
\hline $\mathrm{NO}_{3}^{-}\left(\mathrm{mg} \mathrm{l}^{-1}\right)$ & 0.70 & 0.72 \\
\hline $\mathrm{NO}_{2}^{-}\left(\mathrm{mg} \mathrm{l}^{-1}\right)$ & 0.05 & 0.05 \\
\hline $\mathrm{NH}_{4}^{+}\left(\mathrm{mg} \mathrm{l}^{-1}\right)$ & 0.210 & 0.215 \\
\hline Total nitrogen $\left(\mathrm{N}_{\text {tot }}\right)\left(\mathrm{mg} \mathrm{l}^{-1}\right)$ & 3.0 & 3.58 \\
\hline Organic nitrogen $\left(\mathrm{mg} \mathrm{l}^{-1}\right)$ & 2.1 & 2.6 \\
\hline $\mathrm{PO}_{4}{ }^{3-}\left(\mathrm{mg} \mathrm{l}^{-1}\right)$ & 0.63 & 0.72 \\
\hline Total phosphorus $\left(\mathrm{P}_{\text {tot }}\right)\left(\mathrm{mg} \mathrm{l}^{-1}\right)$ & 0.65 & 0.74 \\
\hline Organic phosphorus $\left(\mathrm{mg} \mathrm{l}^{-1}\right)$ & 0.02 & 0.03 \\
\hline $\mathrm{Mg}^{2+}\left(\mathrm{mg} \mathrm{l}^{-1}\right)$ & 12.25 & 12.50 \\
\hline $\mathrm{K}^{+}\left(\mathrm{mg} \mathrm{l}^{-1}\right)$ & 10.85 & 11.20 \\
\hline $\mathrm{Na}^{+}\left(\mathrm{mg} \mathrm{l}^{-1}\right)$ & 76.90 & 77.73 \\
\hline $\mathrm{Fe}^{2+}\left(\mathrm{mg} \mathrm{l}^{-1}\right)$ & 0.157 & 0.163 \\
\hline $\mathrm{Ca}^{2+}\left(\mathrm{mg} \mathrm{l}^{-1}\right)$ & 39.79 & 40.50 \\
\hline
\end{tabular}


net was cast and dragged at $20-30 \mathrm{~cm}$ depth for $\mathrm{ca}$ $1.5 \mathrm{~m}$ along the banks.

Microscopic analyses were made using a Nikon Eclipse TE 2000-S inverted light microscope fitted with a Nikon DS-Fil camera. Morphological observations were conducted at $600-1000 \times$, enabling careful observation of those features. Quantitative analyses followed Utermöhl (1958).

Water samples for physicochemical analyses were filtered through Millex HV13, Sep-Pak PLUS CM and Sep-Pak C18 PLUS filters. Organic nitrogen and total phosphorus were determined using PN-73 C-04576 and PN-EN-ISO-11885. Content of nitrates and phosphates was analyzed with an PLC ion chromatograph (photoLab S12 Calorimeter). Ammonium was determined by calorimetric analysis with a Mark II Braun+Luebbe analyzer. Element content $(\mathrm{Ca}, \mathrm{Mg}, \mathrm{K}, \mathrm{Na}$ and $\mathrm{Fe}$ ) of the samples was determined by ICP-AES on a Varian spectrometer (PN-EN-ISO 11885). Water $\mathrm{pH}$ and conductivity was determined by $\mathrm{PN}-90 / \mathrm{C}-0440.01$, and oxidation by PN-EN-ISO 8467. Color was determined by calorimetry (photoLab S12 Calorimeter). The physicochemical analyses were done twice, in April 2006 and August 2007.

\section{RESULTS AND DISCUSSION}

Phacus bętkowskii Stawiński

Figs $2 \& 3$

Acta Hydrobiol. 11(1): 49.

EMENDED DESCRIPTION. Cells with apical groove, green, rigid, leaf-shaped, solitary, nonmotile, free-floating in plankton. Cells flattened, (38.6-)40.0-42.85(-44.2) $\mu \mathrm{m}$ long, (30.0-)33.0$35.5(-36.0) \mu \mathrm{m}$ wide, $(20-) 22-23(-24) \mu \mathrm{m}$ thick. Cells pear-shaped, slightly narrowing towards top. Apical furrow reaching half the cell, located at top. Posterior end wider, with slightly curved or straight, short, verrucose caudal process. Cells covered diagonally with striped pellicle; stripes delicate, smooth and parallel. Chloroplasts numerous, small, 3-4 $\mu \mathrm{m}$ in diameter, tiled, without pyrenoids. Two big paramylon granules, ring-shaped, $10-15 \mu \mathrm{m}$ in diameter, and (15-)20-30 smaller ones. Eyespot clearly visible, 5-6 $\mu \mathrm{m}$ in diameter. The majority of cells embedded in amorphous gelatinous matrix (palmella stage) (46-)50-58(-67) $\mu \mathrm{m}$ in diameter, without flagella. Cells rarely occur without gelatinous matrix; when they do, a flagellum as long as
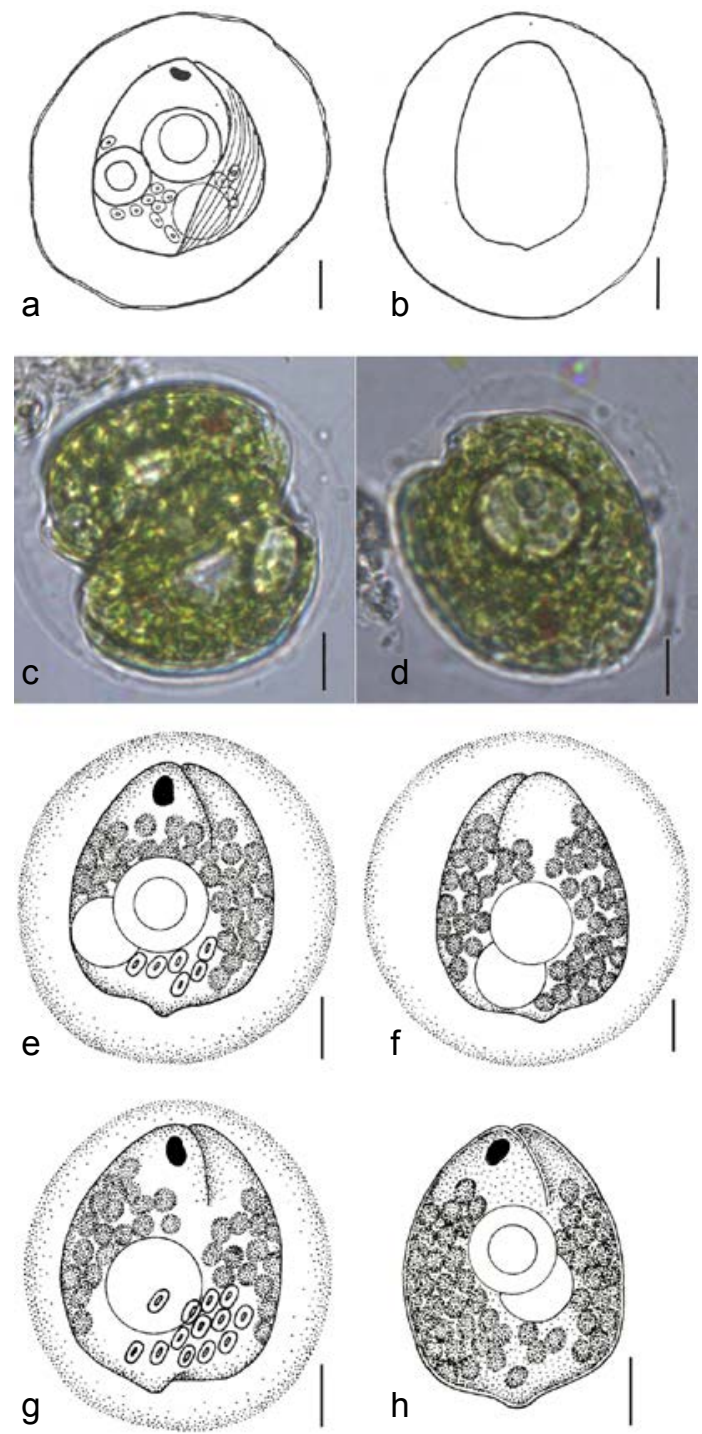

Fig. 2. Phacus bętkowskii Stawiński, a-g - palmella stage, $\mathrm{c}$-cells after division, $\mathrm{h}$ - cells without amorphous gelatinous matrix, $\mathrm{c}-\mathrm{h}-\mathrm{cells}$ with visible shape of chloroplasts and paramylon bodies, $\mathrm{g}$ - cell with a slightly curved caudal process. Scale bars $=10 \mu \mathrm{m}$ (a \& b according to Stawiński 1969).

the cell or shorter can be observed. Cells without gelatinous matrix of the same shape and size as palmella stage.

Distribution And ECOlogy. Phacus bętkowskii is known from two localities in Poland so far (Fig. 1). It grows in midfield pond 

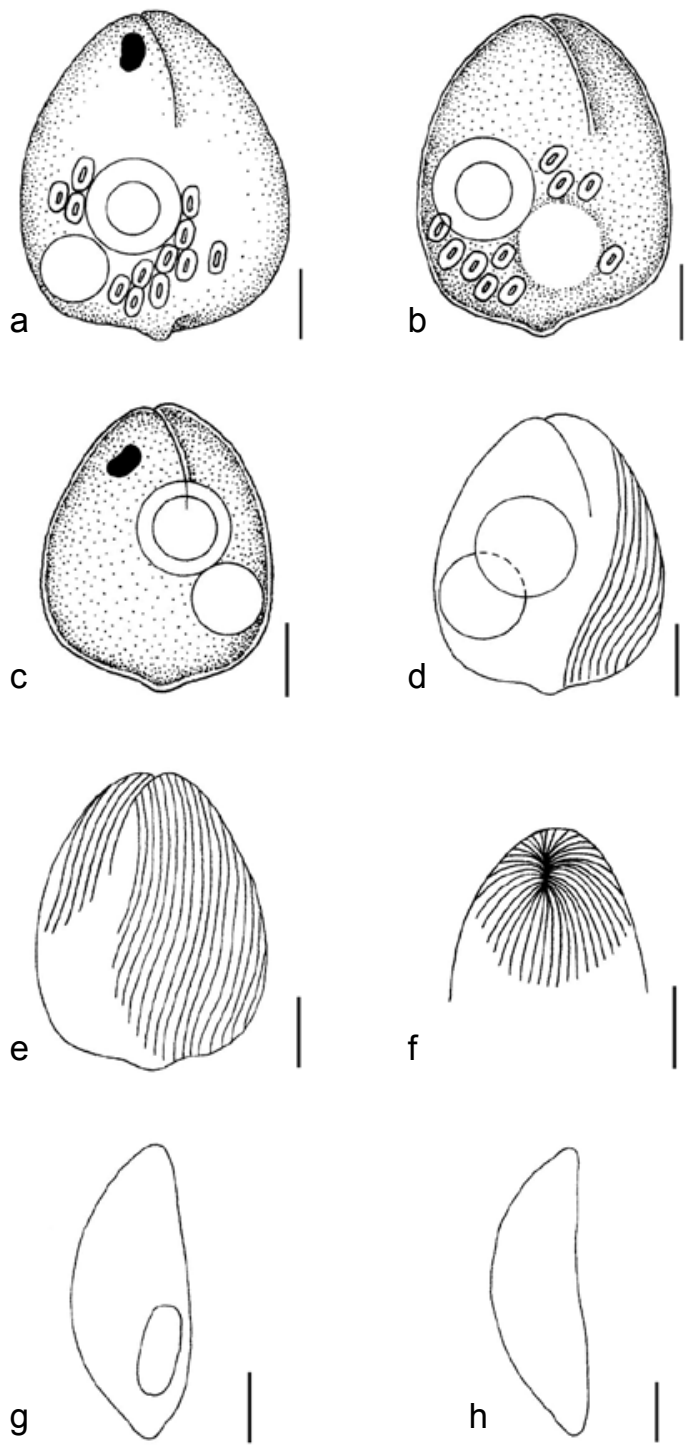

Fig. 3. Phacus bętkowskii Stawiński, a-e-cells without amorphous gelatinous matrix, $\mathrm{d}-\mathrm{f}-$ surface patterns, $\mathrm{g} \& \mathrm{~h}-$ flattened cells. Scale bars $=10 \mu \mathrm{m}$.

plankton (littoral zone), occurring intermixed with Ph. acuminatus among Ophiocytium bicuspidatum, O. parvulum and Tribonema viride and at the bottom of pond (benthos). The physicochemical properties of the water (Table 1) and composition of the macrophyte vegetation suggest that Ph. bętkowskii prefers high-trophy (eutrophic) water bodies.
Notes. The observations of abundant material of Ph. bętkowskii found in Faroży pond in Landek village added to the limited data on its morphology provided by Stawiński (1969) and enabled better separation from some similar species. Phacus bętkowskii is somewhat similar to Ph. abrupta Korshikov in size but differs from it by having a papilla instead of a tailpiece and by the shape of paramylon bodies. Three other species can be confused with $P h$. betkowskii: $P h$. acuminatus Stokes, Ph. curvicauda Svirenko and Ph. stokesii Lemmerm. Phacus bętkowskii differs from $P h$. acuminatus by having noticeably larger cells $[40.0-42.9 \times 33.0-35.5 \mu \mathrm{m}$ versus (20-)23-30 × (23-)25-40 $\mu \mathrm{m}]$ and a caudal process $(P h$. bętkowskii - posterior end with slightly curved or straight, short verrucose caudal process; Ph. acuminatus with smooth, short extension), but from $P h$. curvicauda it differs in the character of posterior ends (posterior ends with papilla in Ph. bętkowskii and curved cauda in Ph. acuminatus). Phacus stokesii differs from Ph. bętkowskii by the presence of one paramylon body only and slightly larger cell size.

ACKNowledgements. I thank Professor Konrad Wołowski (W. Szafer Institute of Botany, Polish Academy of Sciences, Kraków, Poland) for confirming the determination and the anonymous reviewers for valuable remarks and suggestions on the manuscript.

\section{REFERENCES}

EsSEN H. J. \& LEANDER B. S. 2010. Evolution of distorted pellicle patterns in rigid photosynthetic euglenids (Phacus Dujardin). Journal of Eukaryotic Microbiology 57(1): 19-32.

KŁosowsKi S. 1992. Temporal and spatial variation of habitat conditions in the zonation of littoral plant communities. Aquatic Bot. 43: 199-208.

KočÁRková A., Wolowski K., PoulíčKová A. \& Lelková E. 2005. Phacus Dujardin 1841 and Monomorphina Mereschkovsky 1877 taxa (Euglenophyta) occurring in the pools of Poodří and Litovelské Pomoraví Protected Landscape Areas (Czech Republic). Algol. Stud. 118(1): 63-77.

Round F. E. 1984. The ecology of algae. Cambridge University Press, Cambridge, New York, New Rochelle, Melbourne, Sydney.

StaRmaCH K. 1968. Xanthophyceae - Różnowiciowe. Flora 
słodkowodna Polski 7. Państwowe Wydawnictwo Naukowe, Warszawa - Kraków.

Starmach K. 1983. Euglenophyta - Eugleniny. Flora Słodkowodna Polski 3. Państwowe Wydawnictwo Naukowe, Kraków - Warszawa.
STAWIŃSKI W. 1969. Arten der Gattung Phacus, welche in verschiedenen Biotopen der Umgebung von Bielsko-Biała vorkommen. Acta Hydrobiol. 11(1): 1-55.

UtermöHL H. 1958. Zur Vervollkommung der quantitative Phytoplankton-Methodik. Mitt. Internat. Verein. Limnol. 9: $1-38$.

Received 20 March 2014 